\title{
PENYALAHGUNAAN HAK DAN WEWENANG ORGANISASI \\ MASYARAKAT DI KELURAHAN KEDAUNG, TANGERANG \\ SELATAN, BANTEN
}

\section{Dwi Putranto Priyono ${ }^{1}$,Wati Nilamsari ${ }^{2}$}

\author{
Universitas Islam Negeri Syarif Hidayatullah Jakarta
}

dwi.putranto18@mhs.uinjkt.ac.id

$\underline{\text { Received : } 9 \text { June } 2021 \text { |Reviewed: } 17 \text { July } 2021 \text { | Accepted: } 5 \text { September } 2021}$

\begin{abstract}
ABSTRAK
Organisasi Masyarakat pada awalnya terbentuk guna menampung aspirasi dari setiap masyarakat di setiap daerah di Indonesia. Organisasi Masyarakat atau biasa disebut Ormas, merupakan salah satu wadah utama dalam proses kemerdekaan. Organisasi Masyarakat adalah kumpulan dari individuyang membentuk suatu kelompok yang diakuisisi oleh negara, baikformal mauoun informal. Namun di satu sisi, seiring dengan perkembangannya, fung si Ormas sebagai wadah pergerakan bagi masyarakat beralih fungsi menjadi bentuk gerakan yang condong negatif. Penelitian ini bertujuan untuk mengetahui beberapa permasalahan sosial yang diakibatkan oleh adanya penyalahgunaan hak wewenag Ormas di kelurahan Kedaung. Adapun latarbelakang permasalahan yang sudah dirumuskan kedalam beberapa pertanyaan, antara lain apa yang melatar belakangi terjadinya bentrokan antar Organisasi Masyarakat bisa terjadi, Apa kebijakan yang sudah ditetapkan pemerintah untuk menyikapi permasalahan ini serta apa pengaruh bagi warga yang tidak terlibat dengan konflik antar Ormas. Pengamatan ini merujuk pada analisis paradigma mobilisasi sumber untuk menjawab rumusan masalah terkait konflik antar Ormas yang terjadi di kelurahan Kedaung bisa terjadi sehingga perebutan sumberdaya berupa lahan bisa menyebabkan permasalahan sosial yang mengganggu warga sekitar Kedaung. Penelitian pada jurnal ini menerapkan metode kualitatif berupa wawancara, observasi dan beberapa studi literatur. Penelitian ini menilai bahwa Ormas yang ada di kelurahan kedaung saling memperebutkan sumber daya yang berupa lahan. Lahan yang disebut adalah lahan
\end{abstract}

\section{Korespondensi:}

Universitas Islam Negeri Syarif Hidayatullah Jakarta

Jl. Ir H. Juanda No.95, Cemp. Putih, Kec. CiputatJUR NAL ILMIAH DINAMIKA SOSIAL 5 (2) $2021 \mid 253$

Tim., Kota Tangerang Selatan, Banten 15412

dwi.putranto18@mhs.uinjkt.ac.id 
parkir yang ada di beberapa minimarket dimana mereka melakukan pungli kepada pengunjung minimarket.

Kata Kunci: Ormas, Konflik, Pemerintah

\begin{abstract}
Community Organizations were originally formed to accommodate the aspirations of every community in every region in Indonesia. Community Organizations or so-called Ormas, is one of the main forums in the independence process. Community Organization is a collection of individuals whoform a group that is acquired by the state, bothformal and informal. But on the one hand, along with its development, the function of CSOs as a forum for movement for the community has shifted its function into a form of movement that tends to be negative. This study aims to find out some of the social problems caused by the abuse of the rights of civil society organizations in the Kedaung village. The background of the problem that has been formulated into several questions, including what is the background of clashes between Community Organizations canoccur, what policies have been set by the government to address this problem and what are the effects on residents who are not involved with conflicts between CSOs This observation refers to the analysis of the paradigm of resource mobilization to answer the formulation of problems related to conflicts between CSOs that occur in the Kedaung village so that the struggle for resources in the form of land can cause social problems that disturb residents around Kedaung. Research in this journal applies qualitative methods in the form of interviews, observations and several literature studies. This study assesses that the existing CSOs in the Kedaung sub-district fight over resources in the form of land. The so-called land is a parking lot in several minimarkets where they make extortion to minimarket visitors.
\end{abstract}

Keywords: CSOs, Conflict, Goverment

\title{
PENDAHULUAN
}

Organisasi Masyarakat atau biasa disebut Ormas sudah eksis dan bermunculan sejak zaman kolonial. Ormas berfungsi guna menampung aspirasi dari rakyat dimana rakyat disini bertugas guna menjaga kestabilan demokrasi negara. Namun seiring dengan perkembangan zaman, Ormas yang dirasa memiliki hak dan wewenang atas suatu wilayah tertentu menyalah gunakan hak dan wewenangnya guna kepentingan internal, salah satunya adalah konflik antar Ormas di kelurahan Kedaung ini. Seringkali beberapa Ormas saling bentrok untuk memperebutkan wilayahnya dan membuktikan bahwa merekalah yang berkuasa atas wilayah tersebut, bahkan tak jarang dari konflik tersebut menyumbangkan korban, dari anggota Ormas itu sendiri maupun warga sekitar yang kebetulan sedang melintasi di area konflik tersebut yang dianggap musuh oleh Ormas tersebut di tengah-tengah konlfik yang memanas. Jumlah Ormas sendiri yang ada di kota Tangerang Selatan berjumlah 273 Ormas dan terdaftar di situ resmi pemerintah kota Tangerang Selatan. Namun Ormas yang seringkali terlibat bentrok di 
kelurahan Ciputat ini antara lain PP (Pemuda Pancasila) dan FORKABI (Forum Komunikasi Anak Betawi), alasannya pun hanya karena hal sepele, yaitu membuktikan eksistensi.

Kini, hubungan antara beberapa Organisasi masyarakat dan partai politik, hubungannya bagaikan simbiosis parasitisme dimana yang satu diuntungkan dan satunya lagi dirugikan (Putra et al., 2013). Bagi beberapa partai politik, Ormas merupakan salah satu potensi yang dapat dikonversikan menjadi kekuatan suara politik. Tak jarang lagi-lagi menjelang pemilu, Ormas di kelurahan Kedaung ini saling bentrok karena hal sepele seperti anggota Ormas A yang menyusup ke wilayah Ormas B untuk mengkampanyekan calon dari partai politik yang menggandeng partai A. Organisasi Kemsayarakatan harus bisa menempatkan kedudukannya sebagai suatu independent agar terlepas dari semua kekuatan politik. Sehingga, Ormas diharapkan mempunyai kualitas dan kekuatan, serta potensi yang tinggi terhadap suatu kekuatan politik. Dan pada akhirnya, Partai politik tersebut ikut dan memperjuangkan tujuan visi misi Ormas tersebut untuk bisa diperjuangkan di kancah legislatif dan eksekutif.

Akar dari rumusan masalah pada observasi kali ini adalah bagaimana pemerintah membuat kebijakan dalam menanggapi konflik antar Ormas yang teribat gesekan di sekitaran kelurahan Kedaung. Rumusan masalah yang akan dibahas dan dianalisis dalam penelitian kali ini yaitu : 1. Apa saja manfaat, fungsi, tujuan Ormas, serta apa hak dan wewenangnya dinegara Indonesia?, 2. Bagaimana kronologis konflik antar Ormas di kelurahan Kedaung serta apa faktor penyebabnya?, 3. Apa respon pemerintah daerah dalam menaggapi konflik antar Ormas di keluarah Kedaung?. Didasarkan kepada uraian tersebut, maka jurnal ini ditujukan untuk membahas secara lebih mendalam mengenai fungsi, hak dan wewenang Ormas serta menganalisis lebih dalam mengapa konlfik tersebut bisa terjadi.

\section{KAJIAN TEORI}

Ada beberapa asumsi teoritis mengenai teori mobilisasi sumber daya, yang pertama, gerakan sosial harus dianalisis sebagai suatu model konflik aksi yang sifatnya kolektif atau menyeluruh. Kedua, aksi institusional dan noninstitusional tida terdapat perbedaan diantara keduanya, aksi yang bersifat institusional maupun noninstitusional berisikan konflik yang didasari atas suatu kepentingan yang terorganisis. Dan yang ketiga, gerakan sosial pada umumnya menyertakan tujuan yang rasional dari berbagai kepentingan melalui kelompok yang saling berkonflik atau berkompetisi (Zainuddin, 2016). Antony Giddens memaparkan bahwa gerakan sosial merupakan suatu upaya kolektif guna mencapai kepentingan suatu kelompok, dimanan kelompok masyarakat tersebut melakukan gerakan tersebut guna mencapai tujuan bersama melalui yang disebut gerakan kolektif (collective action) (Nadia, 2019).

Di Indonesia, studi mengenai gerakan sosial pada awalnya berfokus pada gerakan perlawanan antara rakyat marginal dengan kekuasaan otoriter yang dirancang oleh pemerintah. Gerakan hegemoni bisa terjadi akibat bertambahnya kekuasaan pemerintah negara sehingga menimbulkan gesekan atau melemahnya hubungan antara negara dan rakyat. Melalui peristiwa itulah, maka gerakan rakyat yang dilakukan secara kolektif disebut gerakan sosial atau social movement. Gerakan sosial pada dasarnya bertujuan untuk mewujudkan perubahan sosial suatu negara ke arah yang lebih baik sesuai keinginan dan kebutuhan rakyat. Teori mobilisasi sumber daya berfokus pada kata "mobilisasi", dimana kata tersebut memiliki arti pembentukan suatu 
kumpulan masyarakat (kerumunan), asosiasi, dan organisasi dalam menggapai tujuan bersama (Subaktiar, 2020). Organisasi gerakan sosial bisa didefinisikan sebagai suatu organisasi yang memiliki identitas, pada umumnya bersifat formal dan kompleks, dengan visi dan misi memajukan organisasi serta mencapai tujuan organisasi secara kolektif melalui gerakan sosial yang mereka lakukan (Sukmana, 2016).

Dari pandangan teori diatas kita dapat memahami bahwa sumber daya untuk dimanfaatkan oleh suatu gerakan sosial dimana mereka berlomba-lomba untuk mendapatkan sumber daya yang sebanyak-banyaknya untuk menghasilkan keuntungan. Charles Tilly mengatakan bahwa salah satu mengapa gerakan sosial bisa terjadi adalah karena ada figur/tokoh yang memimpin dan memprakarsai adanya mobilisasi sumber daya tersebut (Sari, 2017). Tindakan tersebut dapat berupa tindakan rasional ataupun irasional dan merupakan tindakan instrumental untuk mencapai kepentingan dan tujuan politik tertentu (Sari, 2017). Dapat direfleksikan bahwa adanya ketidakpuasan sosial yang muncul ditengah masyarakat terjadi akibat adanya kesadaran akan ketidakadilan yang terjadi karena tekanan dan intervensi kebijakan oleh negara. Rasa ketidakadilan dan diskriminasi dapat timbul karena terjadinya kesenjangan antara keinginan masyarakat dan kemampuan negara untuk merealisasikan sejumlah harapan masyarakat.(Sari, 2017)

McCarthy and Zald (1977), mengemukakan beberapa hal penting dalam melakukan mobilisasi sumber daya berupa support yang kuat, strategi dan hubungan dengan masyarakat. Gerakan sosial yang dimaksud bukanlah suatu gerakan yang dilakukan secara sembunyisembunyi atau tertutup, melainkan secara terbuka dan cenderung memiliki hubungan yang erat antar organisasi lainnya (Sari, 2017). Pendekatan teori mobilisasi sumber daya mengemukakan bahwa keanekaragaman sumber daya harus didistribusikan dan dimobilisasikan dalam gerakan sosial secara adil dan menyeluruh untuk menghindari adanya konflik perebutan sumber daya antar kekuatan. Hal ini memaksa pemerintah untuk menyusun strategi guna mengontrol suatu gerakan sosial yang terjadi.

Dari beberapa paradigma diatas bisa disimpulkan bahwa Ormas yang ada di kelurahan Kedaung yang tengah terlibat konflik memiliki motif tersendiri mengapa mereka terlibat dalam bentrokan antar Ormas tersebut, antara lain adalah sumber daya atau berupa lahan penghasilan yang ilegal berupa pungli (pungutan liar). Hal ini disebabkan pemimpin atau pemangku kekuasaan di Ormas tersebut yang menginginkan adanya perebutan sumber daya.

\section{METODE PENELITIAN}

Observasi kali ini menganalisis fenomena yang terjadi menggunakan metode kualitatif dimana sang peneliti adalah instrument penelitian itu sendiri. Adapun teknsik untuk mendapatkan beberapa data penelitian yang akurat berupa wawancara kepada beberapa narasumber, pengamatan secara langsung ke tempat kejadian dan studi literatur. Penelitian pada pembahasan kali ini bertujuan guna menyajikan gambaran serta menganalisisnya mengapa fenomena kekerasan yang disebabkan oleh Organisasi Kemasyarakatan di kelurahan Kedaung bisa terjadi. Penelitian ini disajikan secara naratif dengan menjabarkan hasil temuan berupa hasil wawancara, observasi, studi literatur, dan temuan lainnya. 


\section{PEMBAHASAN}

\section{Sejarah Singkat Berdirinya Ormas di Indonesia}

ORMAS atau Organisasi Masyarakat merupakan bukti bahwa suatu negara menjalankan asas demokrasi dan HAM, dikarenakan dalam suatu organisasi masyarakat, mereka memahami adanya hak akan kebebasan berserikat, berkumpul serta menyampaikan pendapat, dimana ketiga poin tersebut mereperesentasikan kebebasan (Subaktiar, 2020). Mereka memiliki peran yang cukup besar dalam menjalankan pembangunan sosial yang efektif melalui proses industrialisasi, urbanisasi dan edukasi. Hal tersebut membantu memicu kesadaran masyarakat proletar untuk merancang beberapa organisasi sosial modern pada abad ke-20, peristiwa tersebutlah yang menjadi alasan terbentuknya beberapa Ormas di negara Indonesia. Sampai saat ini, banyak beberapa Ormas yang tersebar di seluruh daerah di negara Indonesia yang diakui secara konstitusi secara formal ataupun informal. Dimana Organisasi Masyarakat tersebut turut serta dalam mengawasi jalannya kepemeritahan agar berjalan sesuai asas demokrasi.

Dalam sejarah Indonesia, kemunculan beberapa Organisasi Masyarakat membuktikan, bahwa mereka ikut serta dalam mengusir penjajah di Nusantara, contohnya adalah Organisasi Boedi Utomo. Boedi Utomo merupakan Organisasi dalam bidang pendidikan, sekaligus menjadi organisasi tertua di Indonesia yang didirikan oleh pribumi. Organisasi ini terbetuk pada tanggal 20 Mei tahun 1908 dan disebut sebagai pelopor kebangkitan nasional (W. I. Pramono \& Munandar, 2020). Artinya, peran Ormas dalam berpartisipasi membangun negara Indonesia merupakan aksi nyata, Organisasi Masyarakat memang dirancang sebagai wadah penyalur aspirasi bagi masyarakat guna mengawasi kegiatan demokrasi yang ada di Indonesia. Keberadaan Ormas sangatlah penting hingga saat ini, dikarenakan semua persoalan yang menyangkut pautkan rakyat seperti ekonomi, sosial dan budaya tidak semua dapat dipegang oleh pemerintah. Oleh karena itu, Ormas harus bisa berpartisipasi dan mendukung jalannya kepemerintahan guna menciptakan bangsa yang maju dan sejahtera.

Pasca kemerdekaan Indonesia, pekembangan Ormas mengalami kemajuan yang begitu pesat. Pada saat itu, Organisasi masyarakat dapat tumbuh dan berkembang dengan merancang struktur organisasi serta AD/ARTnya sendiri yang di support oleh beberapa masyarakat yang baru merasakan kemerdekaan Indonesia. Diluar hal itu, beberapa kelompok elit berusaha mengintervensi sistem tatanan negara untuk nantinya dijadikan negara dengan demokrasi parlementer. Hal itu menyebabkan Ormas yang mulai berkembang dan maju mengalami kemunduran terecara signifikan. Bahkan akibat terjadinya krisis politik dan ekonomi pada masa itu, terjadi gesekan dalam masyarakat, hal inilah yang menghambat laju perkembangan dan kemajuan Organisasi Masyarakat di Indonesia.

Nasib Organisasi Kemasyarakatan kemudian mencapai titik terendahnya pada saat masa kepemerintahan presiden Ir. Soekarno. Hal ini terjadi akibat beberapa upaya elit kekuasaan untuk memperkuat negara. Pada periode kepemimpinan demokrasi terpimpin, suara masyarakat dimanfaatkan untuk dijadikan instrument legitimasi pada ranah politik. Hal ini berdampak pad a masyarakat yang ingin mengutarakan kebebasan berpendapatnya, karena akan dianggap sebagai pembangkang negara dan dituduh sebagai masyarakat yang mendukung 
adanya revolusi. Sama halnya dengan politik, kekuatan dari pengaruh ideologisasi menyebabkan kedudukan politik mengancam kesejahteraan sosial.

Pada masa kepemerintahan presiden Soeharto atau Order Baru, menimbulkan dampak yang signifikan dalam perkembangan Organisasi Kemasyarakatan di Indonesia. Pada aspek sosial dan ekonomi, kemajuan industrialisasi telah menghasilkan pertumbuhan ekonomi yang pesat. Mereka juga telah menjadi pencetus terjdinya fenomena perubahan pranata sosial damalm masyarakat Indonesia dengan disingkirkannya pola kehiudpan masyarakat yang condong ke masyarakat agraris. Pada level politik, Pemerintah Orde Baru melanjutkan upaya yang sebelumnya dirancang guna memperkuat posisi negara di segala macam bidang. Hal ini mengakibatkan merosotnya integritas antar masyarakat, intervensi yang kuat dari menimbulkan penyempitan ruang-ruang berpendapat dan beraspirasi yang dulu pernah ada di masa kolonial.

\section{Fungsi, Hak dan Wewenang Organisasi Masyarakat}

Asas dari Organisasi Kemasyarakat sejalan dengan ideologi Pancasila dan UUD 1945, meskipun adajuga Ormas yang dapat mendeklarasikan dirinya sesuai meskipun Ormas tersebut tidak memiliki persamaan persepsi dengan ideologi Pancasila dan Undang-Undang Dasar Tahun 1945. Kebijakan ini memiliki perbedaan dengan kebijakan masa lampau perihal asas Ormas yang harus disamaratakan yaitu berasaskan Pancasila. Ormas juga dibedakan dari segi kegiatannya, Ormas harus dibedakan denga beberapa organisasi lainnya yang memiliki tujuan yang berbeda, contohnya guna mencari keuntungan seperti PT, CV, dll. Dalam melaksanakan dan mewujudkan cita-citanya, Ormas bersifat sukarela, sosial, independen dan demokratis serta tidak mencari keuntungan atau nirlaba.

Di Indonesia sendiri, kedudukan Ormas elah diatur dalam konstitusi yang sah dan diakui oleh negara. Dalam UUD 1945, pasal 28, terdapat jaminan bagi seluruh masyarakat Indonesia untuk berkumpul, berserikat dan berorganisasi untuk menyalurkan aspirasi dengan lisan maupun tulisan. Semua bagian dari masyarakat memiliki hak dan wewenang yang sama guna mensejahterakan dan memperjuangkan setiap hak guna mendukung pembangunan negara. Definisi dari kebebasan menurut Undag-Undang Republik Indonesia tahun 1945 ad alah dengan mendirikan koperasi sebagai lembaga yang dapat mensejahterakan para anggotanya untuk meningkatkan kesejahteraan dalam aspek ekonomi, yayasan atau lembaga, partai politik, badan usaha serta Organisasi Kemasyarakatan. Akan tetapi, semua kebebasan tersebut harus bertumpu pada asas negara Indonesia yang pada hakikatnya adalah negara konstitusi. Semua bentuk lembaga, institusi, badan dan organisasi yang ada di negara Indonesia harus tunduk pada konstitusi dan undang-und ang yang berjalan di Indonesia.

Dalam UU Pasal 5 Nomor 17 Tahun 2013 yang membahas perihal Organisasi Kemasyarakatan, disitu dijelaskan mengenai tujuan Ormas yaitu :

1. Meningkatkan dan menumbuhkan partisipasi dari seluruh bagian dari masyarakat;

2. Memberi bantuan yang layak serta melayani kebutuhan seluruh masyarakat;

3. Memegang erat nilai kepercayaan yang sejalan dengan Pancasila, sila pertama yaitu Ketuhanan Yang Maha Esa; 
4. Menjaga nilai, norma dan budaya dalam kehidupan bermasyarakat;

5. Ikut serta dalam menjaga, melestarikan, dan memanfaatkan dengan bijak sumber daya alam di lingkungan sekitar;

6. Membantu meningkatkan gerakan sosial, gotong royong, saling tolong menolong antar sesama;

7. Menjaga persatuan dan kesatuan bangsa.

Adapun dibahas dalam UU Pasal 6 Nomor 17 Tahun 2013 mengenai fungsi dan manfaat Organisasi Kemasyarakatan antara lain sebagai wadah :

1. Penyalur kegiatan sesuai tujuan dan visi misi organisasi kemasyarakatan;

2. Pemberdayaan, pendampingan kepada seluruh anggota organisasi untuk mewujudkan cita-cita dan tujuan dari organisasi kemasyarakatan;

3. Penyalur suara dan aspirasi seluruh masyarakat;

4. Pemenuhan pelayanan sosial;

5. Pemelihara nilai norma, budaya dan etika dalam kehidupan berbangsa dan bernegara;

6. Partisipasi masyarakat guna menjaga persatuan dan kesatuan banga (Herdiansah, 2016).

Dari point-point tujuan dan fungsi Ormas diatas bisa kita simpulkan bahwa Ormas adalah sebuah wadah dari masyarakat dan untuk masyarakat. Dimana aspirasi itulah yang nantinya akan menjadi suara rakyat guna mempertahankan demokrasi di Indonesia. Ormas bukan hanya sebagai organisasi saja, namun sebagai sebuah lembaga yang memiliki tujuan guna melakukan pemberdayaan kepada masyarakat, adapapun salah satu tujuannya dalam pemberdayaan yaitu meningkatkan partisipasi dari masyarakat untuk menjaga persatuan dan kesatuan bangsa.

Organisasi masyarakat di Indonesia khususnya, memiliki beberapa hak dan wewenang yang diakui secara konstitusi di negara Indonesia, antara lain :

1. Mengatur dan menjalankan struktur keorganisasi secara independen dan transparan;

2. Mendapatkan kekuasaan atas hak kekayaan intelektual untuk penggunaan nama dan simbol Organisasi kemasyarakatan sesuai dengan yang tercantum ketentuan konstitusional;

3. Mewujudkan tujuan Organisasi Kemasmarakatan;

4. Melaksanakan kegiatan dan program organisasi guna mencapai tujuannya yang diharapkan;

5. Mendapatkan perlindungan hukum oelh negara atas perlindungan dalam berorganisasi;

6. Bekerja sama dengan Pemerintah, pihak swasta, dan Organisasi lain, serta pihak lainnya dalam rangka pengembangan dan kemajuan organisasi.

Sejatinya, Ormas di Indonesia memiliki dan bahkan diberikan hak dan wewenang dan sudah tercantum dalam undang-undang, disana sudah diatur agar Ormas memiliki pegangan hukum yang legal dan diakui negara. Ormas diberikan hak untuk mengatur anggaran dasar dan anggaran rumah tangganya sendiri guna keberlangsungan Ormas tersebut, yang didasari oleh tujuan dan cita-cita Ormas tersebut. Namun dalam hal tersebut, Organisasi juga memiliki kewajiban untuk menjaga kesatuan dan persatuan Indonesia. Ormas berkewajiban untuk memelihara dan menjaga nilai budaya, moral, norma, etika dan agama serta menyebarkan manfaatnya untuk mayarakat serta memelihara ketertiban demi tercapainya kedamaian dalam 
masyarakat. Dapat disimpulkan bahwa hak dan wewenang Ormas sudah di cantumkan dalam UU Tentang Organisasi Kemasyarakatan, dimana Ormas memiliki hak untuk mengatur sendiri roda organisasinya dan mengatur AD/RT guna kemajuan Ormas itu sendiri. Ormas juga memiliki kewajiban untuk menjaga persatuan dan kesatuan banga Indonesia.

\section{Dinamika Konlik Antar Ormas di Kelurahan Kedaung}

Konflik sosial merupakan pergesekan atau benturan yang terjadi secara fisik berupa kekerasan antar kelompok, berlangsung dalam suatu waktu dan cenderung menghasilkan dampak yang buruk bagi kehidupan disekitarnya. Suatu Konflik sosial mengakibatkan disintegrasi sosial yang berpotensi mengganggu kestabilitasan negara serta menghambat terjadinya pembangunan sosial secara keseluruhan. Adapun solusi atau pemecahan masalah dari konflik sosial adalah melalui penanganan konflik. Penanganan konflik merupakan suatu uapaya yang dirancang secara sistematis dalam suatu peristiwa, baikpada saat, sebelum ataupun sesudah terjadinya suatu konflik yang berupa pencegahan atau preventif, penghentian atau intervensi dan rehabilitasi sesudah terjadinya suatu konflik yang terjadi. Gareth Jones mengartikan suatu konflik pada level organisasi sebagai "benturan yang terjadi disaat tercapainya tujuan tertentu dari di pelaku dan ditunjukan ke suatu kelompok dengan dirintangi atau digagalkan oleh tujuan kelompok lainnya"(Zainuddin, 2016) . Dari definisi konflik tersebut dapat kita ketahui bahwa konflik yang terjadi antara kelompok Ormas terjadi karena adanya disintegrasi antara kelompok dalam kurun waktu tertentu sehingga menyebabkan distabilitas dan menghambat laju pembangunan nasional. Adapun penyebab memicunya konflik sosial yang dikategorikan menjadi 3 point utama yaitu :

1. Perbedaan karakter antar indivudu yang berkonflik;

2. Situasi dan keadaan tertentu;

3. Kondisi internal keorganisasian (Susanto et al., 2020).

M. Zulfan Tadjoeddin memaparkan, bahwa keadaan sosial, ekonomi dan politik yang cenderung lemah merupakan potensi dimana akan trjadi ledakan kekerasan dan kriminalitas yang tinggi (G. E. Pramono, 2015). Jerome Tadie menegaskan, terdapat beberapa sekelompok orang yang memberikan pengaruhnya dalam hal penataan suatu kota. Mereka biasanya bersifat ekslusif. Sifat keeksklusivan tersebut ada berdasarkan persamaan agama, suku, ras ataupun persamaan identitas tertentu yang menjadi salah satu syarat utama agar kelak menjadi bagian dari anggota suatu organisasi tersebut. Ada beberapa kelompok yang identik dengan kekerasan seperti penjaga lahan, keamanan lokasi hiburan malam, perkantoran, dept collector, pengelolaan parkir, dan lainnya.

Sesuai dengan pernyataan para ahli diatas, bahwa konlfik antar Ormas ini terjadi akibat kondisi sosial, ekonomi dan politik suatu negara yang cenderung lemah dan rapuh. Sehingga sekelompok masyarakat ini membentuk suatu perkumpulan yang disatukan atas kesamaan tertentu seperti suku, agama budaya dan kesamaan identitas lainnya. Hal ini menunjukan bahwa konflik antar Ormas terjadi akibat ketidakstabilan suatu kebijakan pemerintah yang mengakibatkan adanya lonjakan perlawanan berupa kekerasan. Mereka berlomba-lomba untuk 
menyampaikan aspirasi dan bahkan berkompetisi untuk memperkuat diri. Salah satu caranya adalah memperebutkan wilayah kekuasaan dan memperoleh eksistensi yang salah satunya terjadi di keluarah kedaung ini.

Konflik antar Ormas yang terjadi di keluarah kedaung memberikan dampak yang cukup buruk bagi keamanan daerah sekitar, banyak warga yang resah akan kejadian yang memilukan ini. Menurut beberapa sumber yang diwawancarai pada penelitian kali ini, Ormas tersebut seringkali terlibat konflik dikarenakan memperebutkan suatu wilayah tertentu, dimana eksistensi adalah nomor satu. Salah satu contohnya adalah Ormas PP (Pemuda Pancasila) yang terlibat konflik dengan FORKABI (Form Komunikasi Anak Betawi) yang terjadi di jalan aria putra, mereka saling bentrok untuk memperebutkan daerah kekuasaan yang berupa lahan penghasilan, dimana penghasilan tersebut adalah ilegal atau bisa dibilang pungli atau pungutan liar. Adapun yang coba diperebutkan antara lain lahan parkir minimarket, halte, ruko ruko di sekitar dll. Cara mereka mendapatkan penghasilan dari lahan tersebut adalah meminta bayaran atau jatah yang berkedok "duit keamanan".

Ad apun dampak dari penguasaan lahan ini yang betul-betul dirasakan oleh warga dimana kini oknum Ormas tersebut sudah menguasai beberapa fasilitas umum milik pemerintah yang harusnya dikelola oleh pihak pemerintah seperti yang terjadi di salah satu hutan kota dan taman yang berada di daerah ini. Oknum Ormas yang berhasil menempati lahan tersebut dengan semena-mena menetapkan tarif masuk atau uang parkir yang harganya sangat tinggi, adapun tarif untuk motor sebesar 5000 rupiah dan untuk mobil bisa lebih dari 10.000 rupiah. Menurut salah satu informan yang bekerja sebagai tukang sapu di taman tersebut, ada sekumpulan anak muda yang ingin membuat video tugas di taman kota tersebut. Saat sekumpulan anak muda tersebut mengeluarkan kamera, mereka langsung dihampiri oleh oknum Ormas tersebut. Oknum Ormas langsung menuduh anak muda tersebut adalah Youtuber yang ingin membuat konten di taman kota tersebut dan mereka meminta uang sebesar 500.000 rupiah ke pemuda ini. Padahal seharusnya biaya retribusi dan pengelolaan fasilitas umum seperti taman dan hutan kota dikelola langsung oleh pemerintah daerah setempat, namun karena kebijakan yang kurang mereka, oknum Ormas ini mendapatkan celah untuk bisa menjadikan tempat tersebut sebagai lahan penghasilan uang yang ilegal.

Beberapa contoh lainnya yang bukan termasuk konlfik namun sangat menggangu keharmonisan kehidupan masyarakat setempat. Beberapa Ormas yang dirasa memiliki hak dan kekuasaan pada daerah tersebut seringkali membuat suatu acara atau biasa disebut "sekatenan', istilah lain dari pasar malam. Mereka membuat acara tersebut alih-alih membantu para pedagang yang menginginkan lapak yang ramai, namun hal tersebut sampai memblok atau memotong jalan raya dimana langsung terjadi kemacetan. Salah satu contohnya adalah kegiatan pasar malam yang diadakan setiap hari selasa malam di depan perumahan Taman Kedaung. Pasar malam tersebut amat sangat mengganggu warga yang sedang melintas di jalan raya aria putra dimana mereka harus terganggu dengan jalan yang dipotong untuk lahan parkir pengunjung pasar malam dan tak jarang hal tersebut menyebabkan kecelakaan.

Berhubungan dengan teori mobilisasi sumber daya, maka baik itu merupakan aksi institusional maupun tidak yang berisi serangkaian konflik guna mencapai suatu kepentingan yang dibangun dalam kekuasaan yang terorganisir, gerakan sosial yang terjadi pasti melibatkan 
tujuan yang rasional dengan berbagai kepentingan melalui suatu kelompok yang saling berlomba untuk memperoleh sumber daya. Artinya, beberapa Ormas yang terlibat konflik, mereka memiliki kepentingan dan tujuan masing-masing. Cara untuk mendapatkannya, salah satunya adalah dengan telibat konflik atau intervensi, dimana mereka memaksa untuk merebut daerah wilayah kekuasaan dengan cara kekerasan. Dengan harapan bahwa ketika mereka menang, mereka akan menguasai daerah tersebut dan menjadikan beberapa sumber daya yang berada di kawasan tersebut menjadi lahan penghasilan. Seharusnya, mobilisasi sumber daya tidak dilakukan dengan cara kekerasan, sumber daya bisa didistribusikan secara menyeluruh jika suatu gerakan sosial tersebut saling berkaitan erat dan damai agar terciptanya perd amaian.

\section{Hasil Penemuan di Lapangan}

Hasil temuan yang didapatkan dalam penelitian kali ini berasal dari beberapa sumber data diantaranya melalalui observasi secara langsung, studi literatur dan wawancara secara mendalam. Wawancara dilakukan kepada 2 sudut pandang yang berbeda, yaitu oleh anggota non Ormas dan Anggota Ormas itu sendiri, hal ini bertujuan untuk mendapatkan 2 sudut pandang yang berbeda. Wawancara pertama dilakukan ke beberapa narasumber, salah satunya adalah Pak Tri selaku warga perumahan Taman Kedaung, beliau mengatakan seringkali melihat beberapa kelompok Ormas yang terlibat tawuran, "Biasanya pas bulan ramadhan, jam 2-3 pagi mereka suka tawuran di dekat Pom Bensin sebelah RS Soeroso". Narasumber kedua adalah saudara Nita yang juga merupakan salah satu narasumber, ia mengatakan selain konflik, ada beberapa kegiatan yang seringkali dilakukan oleh Ormas yang kerap mengganggu kenyamanan warga saat berkendara, "Saya biasanya pulang sekitar jam 7 malam, setiap malam rabu, biasanya di depan perumahan Taman Kedaung suka diadakan pasar malam atau sekatenan, seringkali mereka ambil seperempat ruas jalan untuk parkir motor, kita sebagai pengguna jalan harus rada tersendat, dan pernah sekali waktu ada yang kecelakaan, seorang pengguna sepeda motor menabrak motor yang sedang terparkir di area pasar karena tidak adanya pembatas". Dari catatan diatas dapat dibuktikan bahwa masyarakat yang tidak tergabung dalam Ormas merasakan akan eksistensi Ormas di kelurahan Kedaung.

Observasi dalam penelitian kali ini dilakukan secara langsung guna mencari tahu beberapa bukti mengenai eksistensi Ormas yang ada di kelurahan Kedaung. Ada beberapa temuan yang menunjukan bahwa Ormas tersebut menjadi penguasa atau pemegang kekuasaan atas daerah atau fasilitas tersebut. Seperti contoh, ada beberapa pos Pemuda Pancasila yang didirikan di beberapa wilayah dengan di cat loreng dominan oranye dan hitam. Ada poster atau baliho yang tentunya ilegal dipasang oleh beberapa Ormas untuk menunjukan eksistensinya. Dalam studi literatur dapat diperoleh data-data terkait guna membantu pelaksanaan observasi. Salah satu hasil studi literatur saya membuktikan bahwa Ormas yang berada di kota Tangsel berjumlah 273 Ormas yang terdaftar di website resmi satpol pp kota Tangerang Selatan. Maka tak jarang "jika" adabeberapa Ormas yang memperebutkan wilayah kekuasaan untuk dijadikan lahan penghasilan.

Salah satu narasumber yang menjadi kunci dalam pencarian jawaban mengapa Ormas di wilayah Kedaung ini seringkali terlibat konflik, adalah melalui satpam Perumahan Taman Kedaung yang bernama Taufan. Ketika Saya bertanya mengapa seringkali terjadi bentrokan 
antar Ormas di sekita kelurahan Kedaung, dan siapa sajakah Ormas yang terlibat dalam bentrokan tersebut. Pak Taufan menjelaskan bahwa yang seringkali terlibat konflik bukanlah Ormas melainkan Oknum yang mengatas namakan dirinya Ormas. Pak Taufan juga mengatakan bahwa mengapa mayarakat mempersepsikan sekelompok yang berkonlfik tersebut adalah anggota Ormas, karena pad a saat mereka terlibat konlfik, ada simbol-simbol atau atribut yang dikenakan. Hal ini tentu ada alasannya mengapa mereka menggunakan atribut dan simnol tersebut, antara lain guna memperkuat nama mereka. Banyak sekali oknum yang menggunakan atribut Ormas untuk beberapa yang melanggar hukum dan norma, mereka menaggap, jika suatu Ormas menguasai lahan atau wilayah tersebut, maka mereka akan tunduk dan ditakuti jika mereka mengatasnamakan diri mereka 'Ormas'.

Dari perbedaan jawaban antara anggota Ormas dan yang bukan anggota Ormas dapat disimpulkan, bahwa ada perbedaan jawaban diantara mereka. Itulah mengapa dalam penelitiany kali ini, dibutuhkan jawaban dari 2 sudut pandang yang berbeda untuk mendapatkan jawaban yang akurat, sebab jika hanya mewawancara masyarakat non Ormas saja, maka Saya hanya akan membahas kejelekan Ormas saja yang belum tentu benar. Melalui jawaban diatas Saya bisa menyimpulkan, bahwa ada proses labeling atau pemberian cap dari masyarakat non ormas kepada Oknum yang mengaku Ormas. Kedua sudut pandang tersebut menjelaskan bahwa persepsi masyarakat sudah berubah, yang tadinya fungsi Ormas adalah menjadi penyalur aspirasi bagi masyarakat, kini menjadi musuh masyarakat.

Adapun penyebab dari kerusuhan yang terjadi merupakan bukan dari anggota Ormas namun merupakan "Oknum" Ormas yang memakai nama suatu Ormas guna memperkuat namanya dikala sedang terjadinya bentrokan. Dirasa memiliki pengaruh yang kuat ditengah masyarakat, Oknum ini sengaja menggunakan atau bahkan menyalahgunakan fungsi, hak dan wewenang dari suatu Ormas untuk bisa mencapai keinginannya. Namun masalah kini muncul pertanyaan, mengapa Oknum tersebut melakukan hal tersebut?. Pak Taufan selaku satpam di Perumahan Taman Kedaung yang berada di kelurahan Ciputat, beliau memaparkan, bahwa salah satu faktor adalah ekonomi, adapun beberapa kegiatan atau upaya oknum ormas ini melakukan hal tersebut guna mendapatkan keuntungan dengan menyalahgunakan hak dan wewenang Ormas. Faktor ekonomi menyebabkan beberapa masyarakat yang memiliki kesulitan dalam ekonomi memaksa mereka untuk mendapatkan uang dengan berbagai macam cara, salah satunya adalah perebutan lahan atau wilayah kekuasaan.

Beberapa contoh lahan yang biasanya diperebutkan seperti minimarket, halte, taman kota, lahan parkir dan beberapa fasilitas umum lainnya. Dengan mereka menguasai lahan tersebut, mereka mendapatkan sejumlah uang dimana akan mereka setorkan kepada si "pemimpin"dan nanti akan dibagikan kepada anggotanya. Adapun beberapa upaya oknum Ormas yang mereka lakukan guna mendapatkan keuntungan :

\section{Lahan Parkir}

Seringkali kita ketahui bahwa beberapa minimarket memiliki penjaga parkir atau "tukang parkir". Namun sebenarnya, pihak minimarket tidak pernah menyuruh atau merekrut orang untuk dijadikan sebagai penjaga parkir. Kebanyakan mereka adalah oknum Ormas, diaras penghasilan dari menjaga parkir cukup untuk memenuhi kebutuhan sehari-hari, maka 
tidak bisa dipungkiri bahwa lahan parkir adalah salah satu lahan yang sering diperebutkan oleh beberapa oknum Ormas.

\section{Uang Keamanan}

Dipasar seringkali kita mendengar istilah "Uang Keamanan", dimana oknum yang menguasai wilayah tersebut meminta kepada pedagang pasar untuk menyetorkan uang keamanan kepada mereka. Padahal peraturan dari pemerintah yang mengelola pasar tersebut hanya mengharuskan si pemiliki kios untuk hanya membayarkan pajak retribusi saja. Banyak para pedagang yang merasa dirugikan, jika mereka tidak mau membayar maka akan diancam toko atau kiosnya akan dihancurkan.

\section{THR}

Biasanya hal ini terjadi disaat mendekati hari raya Idul Fitri, dimana oknum ini meminta sejumlah uang kepada beberapa masyarakat secara memaksa, dan oknum tersebut biasanya paling sering meminta THR kepada beberapa pelaku usaha yang dirasa berada di wilayah mereka.

\section{Pungli}

Pungli disini terjadi dibeberapa fasilitas umum, seperti taman kota dan halte. Di beberapa halte, seringkali ada beberapa oknum yang menjadikan halte tersebut sebagai pos atau basecamp mereka, padahal halte tersebut adalah fasilitas umum. Seperti contoh ada beberapa halte yang berada di kota Tangsel, dimana saat itu ada beberapa karyawan perusahaan penyedia layanan internet rumahan atau $\mathrm{WiFi}$, sedang ingin memasang kabel yang letaknya pas berada diatas halte tersebut. Namun ketika karyawan tersebut ingin melakuka pekerjaannya, ada beberapa oknum yang meminta jatah kepadanya karena dirasa halte tersebut adalah miliknya. Alasannyapun sangat klasik, yaitu untuk membeli rokok dan kopi. Contoh lain ada di taman kota menteng yang berada di kawasan Bintaro dan Jombang, Tangerang Selatan. Ada beberapa oknum yang meminta sejumlah uang kepada beberapa pemuda yang ingin mengerjakan tugas berupa pembuatan video di taman tersebut. Tarifnya pun bisa sampai 500.000, oknum tersebut awalnya menuduh bahwa pemuda yang ingin mengerjakan tugas tersebut adalah Youtuber, karena mereka rasa, Youtuber memiliki banyak uang.

\section{Aksi Kekerasan (Memalak)}

Hal ini sudah lumrah dan seringkali terjadi di kelurahan Kedaung, dimana ada beberapa Ormas yang melakukan aksi kekerasan terhadap masyarakat, mau itu yang dirasa mereka musuh dari mereka ataupun masyarakat biasa. Eksistensi adalah segalanya bagi sejumlah oknum yang mengatas namakan mereka Ormas, karena dengan memperebutkan eksistensilah mereka akan mendapatkan sejumlah lahan penghasilan yang luas. Aksi kekerasan ini kadang terjadi saat ada beberapa orang yang dirasa musuh mereka lewat di area mereka, melalui hal sepele seperti ini maka akan muncul konflik terusan dimana memunculkan dendam diantara kelompok oknum tersebut, dan karena itulah seringkali terjadi tawuran antara kelompok oknum yang mengaku dirinya Ormas di sekitar kelurahan Kedaung. 
Dari beberapa point diatas dapat kita simpulkan, bahwa oknum tersebut menggunakan nama Ormas untuk menambah kekuata dalam menjalankan aksinya. Padahal, menurut narasumber pak Taufan, anggota Ormas yang sesungguhnya tidaklah melakukan hal seperti itu, justru mereka akan saling tolong menolong kepada sesama untuk sama-sama mensejahterakan masyarakat. Anggota Ormas yang baik adalah yang ikut berpartisipasi dalam pembangnan dan keamanan bangsa, bukan malah saling bernkonflik untuk memperebutkan suatu hal yang tidak perlu. Ormas merupakan wadah penyalur aspirasi bagi masyarakat, jika keberadaan Ormas dinilai buruk oleh warga, maka akan dipasktikan fungsi Ormas sebagai penjaga persatuan dan kesatuan bangsa tidaklah berjalan dengan semestinya.

Setelah melakukan observasi dan pengamatan secara menyeluruh, didapatkan beberapa kesimpulan erkait, mengapa konflik ini bisa terjadi dan mengapa masyarakat menganggap bahwa Ormas lah penyebab dari segala macam kerusuhan dan kekerasan yang terjadi di kelurahan Kedaung. Menurut informan yang dimana ia adalah seorang satpam di perumahan Taman Kedaung, yang dimana ia adalah anggota dari Ormas Pemuda Pancasila itu sendiri, ia mengatakan bahwa semua kerusuhan dan kekerasan yang terjadi di kelurahan ked aung untuk memperebutkan wilayah kekuasaan memang betul terjadi, namun pelakunya bukanlah anggota aktif Ormas yang bersangkutan melainkan oknum yang mengatasnamakan diri mereka Ormas. Narasumber menjelaskan bahwa anggota Ormas yang sesungguhnya tidak akan membuat kericuhan, melainkan justru merekalah yang merangkul masyarakat agar bersatu, menjadi wadah aspirasi serta menjaga kestabilan demokrasi di Indonesia. Ormas yang sesungguhnya adalah suatu kelompok yang berserikat membentuk suatu struktur dan sejalan dengan sistem perundang-undangan yang sudah ditetapkan mengenai asas organisasi kemasyarakatan. Bukannya membuat kericuhan, justru Ormas harusnya bisa jadi tempat berlindung bagi masyarakat untuk bersatu yang ditentukan melalui persamaan persepsi.

Meskipun kejadian tersebut dilakukan oleh sejumlah Oknum yang mengaku Ormas, lantas mengapa persepsi masyarakat yang tidak terlibat dalam Ormas menganggap bahwa semua kericuhan dan perilaku menyimpang tersebut disebabkan oleh Ormas?. Hal tersebut terjadi karena terjadinya labeling. Menurut Lemert, labeling merupakan salah satu penyimpangan yang disebabkan karena pemberian label atau cap dari kelompok mayoritas kepada kelompok yang dinilai minoritas dan berpeluang untuk melanjutkan dan merealisasikan penyimbangan tersebut (Erianjoni, 2015). Label yang diberikan kepada pelaku menyimpang biasanya dapat dilihat dari ciri fisik yang menonjol, karakter ataupun kelompok sosial yang memiliki simbol-simbol tertentu (Henslin, 2006). Pemberian cap atau labeling tersebut biasanya didapat setelah tejadinya interaksi sosial. Teori labeling sendiri dilahirkan berdasarkan paradigma interaksionisme simbolik yang kini sudah berkembang kedalam berbagai aspek seperti dalam bidang pendidikan dan bidang kesehatan. Labeling sendiri adalah pemberian identitas oleh suatu kelompok kepada suatu individu karena suatu ciri-ciri tertenu yang tidak sejalan atau sesuai dengan kelompok tersebut (Erianjoni, 2015). Labeling pada dasarnya diberikan kepada suatu individu yang dianggap berperilaku menyimpang dan tidak sesuai dengan norma yang dianut oleh masyarakat (Dirjosisworo, 1994). Namun, label bisa jadi karena hanya sebatas pengelihatan semata (subjektif), akan tetapi merupakan pemberian 
dari suatu kelompok yang mengetahui, menyaksikan sendiri tindakan mereka, baik yang dilakukan secara langsung ataupun tidak langsung (Atwar, 2013).

Dalam upaya menyelesaikan masalah sosial, perspektif ini membahas suatu proses yang dinamakan proses re-definisi dari suatu tindakan yang dianggap sebagai penyimpangan pada masalah sosial tersebut. Dengan dilaksanakannya proses re-definisi atau penginterpretasian ulang, diharapkan mengubah persepsi masyarakat atau kelompok akan seseorang yang tadinya melakukan tindakan dan akan menghentikan tindakannya (Soetomo, 2008). Namun pada kenyataannya dalam proses re-definisi tersebut tetap akan muncul berbagai pandangan entah dari aktor yang dilabeli bermasalah maupun masyarakat yang menilai situasi tersebut sebagai masalah atau bukan.

1. Pertama, diperlukannya proses intervensi diluar pelaku menyimpang untuk memotivasi pelaku untuk mengubah perspektif interpretasinya. Dengan cara memberikan input yang diharapkan mengubah interpretasi seseorang akan dirinya;

2. Kedua, membiarkan semua hal itu terjadi secara alami atau nonintervention. Dalam proses ini, pelaku menyimpang dibebaskan untuk memilih jalannya sendiri untuk dapat memilih lingkungan sosialnya;

3. Ketiga, proses paling ekstrim dari pendekatan ini adalah melalui radical nonintervention, dimana pendekatan ini diperkenalkan oleh Edwin Schur melalui perkataanya yang mengatakan bahwa "leave the deviant alone whenever possible"; (Soetomo, 2008).

Menurut paradigma ini, re-definisi juga dapat dilakukan oleh masyarakat terutama melalui institusi control formal maupun infomal. Sebagaimana diketahui, berdasarkan pola pikir perspektif ini, suatu kondisi atau perilaku dianggap devian atau bermasalah apabila mendapat label sebagai masalah sosial oleh masyarakatnya. Oleh karena itu, proses re-definisi ini haruslah diimplementasikan guna mengedukasi masyarakat yang tidak menjadi bagian dari Ormas bahwa sesungguhnya Ormas yang baik itu tidak akan membuat kegaduhan hanya karena lahan parkir dan adu kekuatan saja. Ormas yang benar adalah yang didalamnya terjadi suatu keterikatan antar anggota dimana mereka memiliki tujuan dan misi yang sama untuk memajukan dan memberdayakan anggotanya, bahkan tak jarang banyak Ormas yang melakukan aksi sosial untuk masyarakat luas. Re-definisi dapat dilakukan oleh pihak Ormas itu sendiri maupun masyarakat yang dinilai sudah paham mengapa hal ini bisa terjadi. Redefinisi bagaikan memberikan edukasi secara menyeluruh agar nantinya masyarakat tidak lagi mengait-kaitkan seluruh kekerasan yang terjadi karena ulah Ormas.

Lantas jika faktor ekonomi adalah penyebab dari permasalahan ini, maka salah satu yang harus dibenahi adalah pembangunan sosial. Menurut Midgley, pembangunan sosial merupakan proses perubahan sosial yang dirancang sedemikian rupa dengan memperhatikan aspek-aspek kehidupan masyarakat guna mensejahterakan masyarakat secara adil dan menyeluruh (Digdowiseiso, n.d.). Midgley juga menjelaskan secara rinci, bahwa ada beberapa aspek yang harus diperhatikan dalam merancang dan mendesain pembangunan sosial:

1. Pembangunan sosial sangat erat kaitannya dengan pembangunan ekonomi, sebab guna mensejahterakan masyarakatnya, maka salah satu kebutuhan yang harus dipenuhi 
adalah perekonomian yang tecukupi. Oleh karena itu, pembangunan ekonomi yang pesat juga harus disinergikan dengan pembangunan sosial yang menyeluruh.

2. Dalam pembangunan sosial, harus ada campur tangan beberapa aspek keilmuan selain sosial, yaitu ekonomi dan politik. Hal ini berdampak pada pengambilan kebijakan yang diambil guna merancang program-program yang akan dilaksanakan guna mensejahterakan rakyat yang sifatnya memaksa dan cenderung mengintervensi.

3. Proses pembangunan sosial harus bersifat intervensi, sebab pembangunan tidak akan berjalan lancar jika dibiarkan secara natural, hal tersebut akan menghambat dikarenakan lamanya proses perubahan sosial. Harus ada campur tangan pelaku kebijakan dalam pembangunan sosial yang mengintervensinya.

4. Pembangunan sosial wajib hukumnya dilaksanakan secara menyeluruh. Dalam hal ini, pembangunan sosial harus dijangkau ke berbagai kelas dan golongan masyarakat guna menciptakan pembangunan yang merata.

5. Pembangunan sosial harus mengangkat kesejahteraan masyarakat secara permanen, artinya pembangunan sosial diharapkan menciptakan masyarakat yang mandiri dan produktif, bukan hanya sekedar memberikan bantuan berupa dana yang habis dikarenakan pengelolaan dan manajemen keuangan yang buruk dari masyarakat itu sendiri.

Hal ini membuktikan bahwa pembangunan sosial yang berada di kelurahan Kedaung belum merata, dibuktikan dengan adanya angka kriminalitas yang terjadi akibat masalah ekonomi. Dalam hal ini, Ormas yang sesungguhnya amat sangat berperan penting guna menjadikan masyarakat lebih sejahtera, sesuai dengan fungsinya, Ormas berfungsi sebagai wadah guna memberdayakan masyarakat agar menjadi masyarakat yang produktif. Dengan adanya masyarakat yang produktif maka bisa dipastikan bahwa angka kejahatan akan menurun jika fungsi dan tujuan Ormas dijalankan dengan baik dan benar. Sinergi antara pembangunan sosial dan ekonomi sangatlah dibutuhkan, karena jika keduanya dilaksanakan secara berdampingan, maka masyarakatnya pun akan sejahtera.

\section{KESIMPULAN}

Dapat disimpulkan bedasarkan penelitian diatas bahwa penyalahgunaan fungsi, hak dan wewenang Organisasi Kemasyarakatan di keluarahan Kedaung dilakukan oleh sejumlah oknum yang mengatas namakan mereka sebagai Ormas. Mereka membawa nama Ormas tersebut untuk memperkuat mereka seakan-akan nama mereka sudah besar dibawah naungan nama Ormas yang mereka gunakan, padahal mereka hanyalah sekelompok orang saja yang ingin mencari kekuasaan atas daerah tersebut. Terbukti jika para oknum ini menyalahgunakan fungsi, hak dan wewenang yang sebenarnya, mereka menggunakan nama Ormas tersebut guna memperkuat eksisitensinya di wilayah kelurahan Kedaung. Pembangunan sosial yang tidak merata juga menyebabkan hal ini bisa terjadi, sebab mereka yang memiliki masalah di perekonomiannya rela melakukan berbagai cara guna mendapatkan uang untuk memenuhi kebutuhan hidupnya. Pemerintah harus berupaya memecahkan masalah ini secepatnya, sebab jika pembangunan ekonomi yang pesat tanpa didampingi pembangunan sosial yang pesat pula, angka kriminalitas akan terus bertambah. 


\section{DAFTAR PUSTAKA}

Atwar. (2013). Bagaimana Individu Menjadi Deviant.

Digdowiseiso,

K. (n.d.).

Teori

Pembangunan

Sosial.

https://www.academia.edu/11498713/Teori_Pembangunan_Sosial

Dirjosisworo. (1994). Sinopsis Kriminologi Indonesia. Bandar Maju.

Erianjoni, E. (2015). Pelabelan Orang Minangkabau Pada Pelaku Penyimpangan Sosial: Studi Kasus Pada Dua Nagari Di Sumatera Barat. Humanus, 14(1), 31. https://doi.org/10.24036/jh.v14i1.5399

Henslin. (2006). Sosiologi Dengan Pendekatan Membumi. Penerbit Airlangga.

Herdiansah, A. G. (2016). Peran Organisasi Masyarakat (Ormas) Dan Lembaga Swadaya Masyarakat (Lsm) Dalam Menopang Pembangunan Di Indonesia. Sosioglobal: Jurnal Pemikiran Dan Penelitian Sosiologi, 1(1), 49. https://doi.org/10.24198/jsg.v1i1.11185

Nadia, N. (2019). Mobilisasi Sumberdaya dalam Aksi Kamisan. Repository.Uinjkt.Ac.Id. http://repository.uinjkt.ac.id/dspace/handle/123456789/49192

Pramono, G. E. (2015). Transformasi Organisasi Kemasyarakatan (Ormas) menjadi Kelompok Kekerasan (Studi kekerasan Ormas di Jakarta). Jurnal Keamanan Nasional, 1(2), 11671180. https://doi.org/10.31599/jkn.v1i2.25

Pramono, W. I., \& Munandar, A. I. (2020). Peran Undang-Undang Ormas Terhadap Penyelesaian Konflik Antar Ormas. Jurnal Ilmiah Living Law, 12(1), 52. https://doi.org/10.30997/jill.v12i1.2296

Putra, W., Sukma, W., Dewa, D., Sanjaya, B., Si, M., Suastika, N., Pd, S., Pd, M., \& Ppkn, J. (2013). Eksistensi Organisasi Kemasyarakatan (Ormas) Dalam Partai Politik di Kecamatan Sukawati. Jurnal Pendidikan Kewarganegaraan Undiksha, 1(1). https://ejournal.undiksha.ac.id/index.php/JJPP/article/view/372

Sari, D. K. (2017). Strategi Mobilisasi Gerakan Masyarakat Dalam Penutupan Industri Pengelolaan Limbah B3 Di Desa Lakardowo Kabupaten Mojokerto. Jurnal Politik Indonesia, 2, 127-134.

Soetomo. (2008). Pemecahannya, Masalah Sosial Dan Upaya. Pustaka Belajar.

Subaktiar, M. I. (2020). Gerakan Mahasiswa dalam Novel Lelaki Di Tengah Hujan Karya Wenri Wanhar ( Kajian Mobilisasi Sumber Daya ). Jurnalmahasiswa.Unesa, 7(4), 10. https://jurnalmahasiswa.unesa.ac.id/index.php/bapala/article/view/35016

Sukmana, O. (2016). Konsep Dan Teori Gerakan Sosial. https://eprints.umm.ac.id/63490/19/Sukmana - Konsep dan Teori Gerakan Sosial.pdf 
Susanto, E., Maftuh, B., Malihah, E., \& Budimansyah, D. (2020). Analisis penanganan konflik antar organisasi kemasyarakatan di Kabupaten Karawang. Jurnal Ilmiah Mimbar Demokrasi, 20(1), 92-96. https://doi.org/10.21009/jimd.v20i1.15666

Zainuddin, D. (2016). Analisis Penanganan Konflik Antar Organisasi Kemasyarakatan Di Sumatera Utara (Medan) Dan Jawa Tengah (Surakarta). Jurnal HAM, 7(1), 10. https://doi.org/10.30641/ham.2016.7.67 